\title{
Rhizosphere Effects of Melocanna baccifera on Soil Microbial Properties under Different Fallow Phases Following Shifting Cultivation
}

\author{
Ramchhanliana Hauchhum $^{1^{\star}}$ and S. K. Tripathi ${ }^{1}$ \\ ${ }^{1}$ Department of Forestry, Mizoram University, Aizawl-796004, India.
}

\begin{abstract}
Authors' contributions
This work was carried out in collaboration between both authors. Author RH designed the study, performed the statistical analysis, wrote the protocol, managed the literature searches and wrote the first draft of the manuscript. Author SKT managed the analyses of the study, edited and reviewed the manuscript. Both authors read and approved the final manuscript.
\end{abstract}

Article Information

DOI: $10.9734 /$ IJPSS/2017/34493

Editor(s):

(1) L.S. Ayeni, Adeyemi College of Education, Ondo State, Nigeria.

Reviewers:

(1) Gaurav Mishra, Rain Forest Research Institute, India.

(2) Wafula Nelson Wekha, Kenyatta University, Kenya.

Complete Peer review History: http://www.sciencedomain.org/review-history/19756

Original Research Article

Received $29^{\text {th }}$ May 2017

Accepted $24^{\text {th }}$ June 2017

Published 29 ${ }^{\text {th }}$ June 2017

\begin{abstract}
Rhizosphere plays an important role in regulating soil fertility and nutrient cycling in different ecosystems. Bamboos are important secondary successional plants in fallow land that have strong impact on the soil fertility of different fallow lands. The main objectives of the present study is to examined the rhizosphere effects of bamboo (Melocanna baccifera) on soil microbial properties (soil organic carbon, SOC; total nitrogen, TN; microbial biomass $\mathrm{C}$ and $\mathrm{N}, \mathrm{MBC}$ and MBN; dehydrogenase activity, DHA; acid phosphatase activity, APA; $\beta$-glucosidase activity, GSA) in rhizosphere (RS) and bulk soil (BS) in shifting cultivation stand with different fallow phase (2 years old, FP-2; 5 years old, FP-5; and 10 years old fallow, FP-10) in Mizoram. The result indicated that soil microbial properties were significantly higher $(p<0.05)$ in RS compared to BS. Further, the level of microbial properties significantly increases in longer fallow (FP-10) compared to shorter fallow (FP-2 and FP-5). On contrary, magnitude of rhizosphere effect of $M$. baccifera was greater in shorter fallow phase compared to longer fallow phase for all microbial properties except in APA and GSA. It was concluded that the rhizosphere effect of bamboo in shorter fallow is microbial mediated
\end{abstract}


under $\mathrm{C}$ and nutrient limited conditions and in longer fallow the same is regulated by the accumulated organic matter and the available nutrients. Further studies are needed to assess the changes in secondary successional plant rhizosphere microbes under different fallow phases.

Keywords: Rhizosphere soil; bulk soil; fallow phase; microbial properties; enzyme activities.

\section{INTRODUCTION}

Since, Hiltner coined the term "rhizosphere", a narrow zone around the roots, in 1904 and observed enhanced diversity of microorganisms in this zone compared to the bulk soil (BS), and emphasized the potential importance of microbial activities associated with root systems in plant nutrition. Majority of published studies on rhizosphere soil (RS) nutrient cycling for trees were conducted on seedlings in microcosms and only few field studies in forests trees are available $[1,2]$. The rhizosphere nutrient cycling of trees under field conditions may vary greatly from that of annual plants and tree seedlings due to their differences in nutrient requirement, soil conditions, as well as growth period [2]. Recently, tree rhizosphere has been reported to greatly affect the global cycling of carbon and nutrients in a changing environment [3]. Therefore, studies on rhizosphere effects of different plants under field condition attract attention of the scientists all over the world where the information is highly limited.

The term 'rhizosphere' is now used in a more general sense to describe the effect of different root systems on soil physical and chemical properties [4]. The rhizosphere zone has been reported as crucial importance for plant health and nutrition [5] and thus rhizosphere microbial processes are important for vegetation development and reestablishment during the process of recovery. Number of researchers have investigated the difference between the microbial communities of RS and BS using phospholipid fatty acid profiles $[6,7,8,9]$ or molecular techniques [10]. The results of these investigations suggested that the differences in rhizosphere microbial community among plant species are largely attributed to the different root exudations. Sinha et al. [11] reported that Aegle marmelos and Azadirachta indica in coal mining areas of Dhanbad, India have diverse effects on rhizosphere soil microbial processes and can be used for reestablishment of vegetation in degraded coal mining areas.

Shifting cultivation is an old age practice of agriculture predominant in Northeast India.
Mizoram is one of the seven sister states of northeast India where majority of the population $(\sim 60 \%)$ depends on agricultural products from shifting cultivation carried out on steep slopes ( half of the total land area is having $40-100 \%$ slopes). This makes the region different from other northeastern states to perform many activities (i.e. slashing, burning, sowing, weeding and harvesting) on these steep slopes, and is responsible for huge loss $\left(\sim 60 \mathrm{t} \mathrm{ha}^{-1}\right)$ of fertile soils every year through erosion [12]. Earlier, the practice was adequately productive, economically feasible and ecologically balanced because of prolonged fallow period ( 20-30 years) but in recent years as a result of exponential expansion of human population, fallow periods have been drastically reduced $(\sim<5$ years) which has led to substantial decrease in soil fertility and crop productivity [13]. Singh et al. [14] recommended about 10-15 years of minimum fallow periods to maintain the soil fertility, particularly $\mathrm{C}$ and $\mathrm{N}$, for sustainable crop production, which are the key factors for the plant growth in the region. Bamboo covers about $57 \%$ of the total forest area of the state where $M$. baccifera is the dominant species among bamboo species and occupies $95 \%$ of the total bamboo forest. Meloccana baccifera is an efficient early colonizer secondary successional species characterized by a woody leptomorph rhizome system [15] that spreads quickly to recover the land after shifting cultivation [16]. Several studies emphasized the role of bamboos in stabilizing nutrient cycling in the early successional fallows of slash and burn agriculture systems of northeast India [17].

Changes in microbial properties of RS have significant influence on the sub sequential growth and health of plants. Melocanna baccifera has been reported to have significant changes on soil fertility following shifting agriculture in subtropical forests $[17,18]$. Therefore, it is important to understand the magnitude of rhizosphere effect of bamboo ( $M$. baccifera) on soil microbial properties. The main objectives of the present study is i) to determine changes in soil microbial properties between BS and RS of $M$. baccifera ii) to understand variation in RS microbial properties in different fallow phases following 
shifting cultivation in Mizoram. We hypothesize that the rhizosphere effect of $M$. baccifera in shorter fallow phase has greater microbial changes than longer fallow phase.

\section{MATERIALS AND METHODS}

\subsection{Site Description and Soil Sampling}

The study was conducted at three different fallow phase (2, 5 and 10 years) in Muallungthu and Tachhip villages in Aizawl district of Mizoram. The 2 years fallow phase (FP-2) is located in Muallungthu (2336.305' $\mathrm{N}$ and 9202.873' E) at $838 \mathrm{~m}$ altitude and the other two sites 5 years fallow phase (FP-5) and 10 years fallow phase (FP-10) are located in Tachhip village (2335.699' $\mathrm{N}$ and 92\%3.096' $\mathrm{E}$ at $740 \mathrm{~m}$ altitude) and (2335.667' $\mathrm{N}$ and 9243.081' $\mathrm{E}$ and at $725 \mathrm{~m}$ altitude) respectively. The ages of fallow lands were identified through interviewing the land owner. The soil of the study sites belongs to order inceptisol and falls under red soil group [19]. Soil is light to medium texture (sandy loam and clay loam) and slope of the land varied between $\sim 35^{\circ}$ and $40^{\circ}$. The mean minimum and maximum temperature of the study sites ranged from $11-21^{\circ} \mathrm{C}$ and $20-30^{\circ} \mathrm{C}$ respectively. The annual average rainfall of the study area is $2350 \mathrm{~mm}$. Soil bulk density ranges from $0.94-1.10 \mathrm{~g} \mathrm{~cm}^{-3}$.

Soils were sampled from the upper $20 \mathrm{~cm}$ depth by excavating 4 soil cores $(5 \mathrm{~cm}$ diameter) from 5 random blocks $(5 \mathrm{~m} \times 5 \mathrm{~m})$ in June, 2013. Twenty soil cores ( 5 blocks $\times 4$ soil cores $=20$ soil cores) were pooled together to have one composite sample of approximately $500 \mathrm{~g}$ from each site. RS was collected by gentle shaking followed by use of a forceps to remove the soil from the live roots and the remaining was considered as BS. Each composite soil was divided into four replicates and the replicated samples were divided into 2 parts: one part was placed in ziplock bag and kept in freezer at $-20^{\circ} \mathrm{C}$ as fresh sample for analysis of microbial properties and the other part was air dried in the laboratory. Microbial biomass and enzyme activities were analyzed before two weeks to avoid alteration of microbes due to freezing.

\subsection{Laboratory Analysis}

Gravimetric soil moisture content (\%) was estimated by oven drying the known weight of field moist soil. Air dried soil (passed through 0.5 $\mathrm{mm}$ sieve) were used to analyzed soil $\mathrm{pH}$, soil organic carbon (SOC) and total nitrogen (TN). Fresh soil samples (passed through $1 \mathrm{~mm}$ sieve) were used to analyze microbial biomass carbon $(\mathrm{MBC})$, microbial biomass nitrogen (MBN), acid phosphatase activity (APA), $\beta$-glucosidase activity (GSA) and dehydrogenase activity (DHA). Soil pH was measured with a glass electrode (1:2.5 soils: water ratio). SOC was determined by the $\mathrm{K} 2 \mathrm{Cr} 2 \mathrm{O} 7$ wet-oxidation method [20] and TN was analyzed using $\mathrm{CHN}$ analyzer (CHNS-O Elemental Analyzer EUROEA, 3000). For determination of soil MBC and MBN, fresh soil samples $(25 \mathrm{~g})$ were subjected to the chloroform-fumigationextraction method [21]. The difference between fumigated and non-fumigated samples in terms of $\mathrm{C}$ and $\mathrm{N}$ was determined and then, $\mathrm{MBC}$ and $M B N$ were calculated using conversion factors, $\mathrm{K}_{\mathrm{EC}}=0.38, \mathrm{~K}_{\mathrm{EN}}=0.45$ respectively $[22,23]$. The APA was determine by method described by Tabatabai [24] and was expressed as $\mu \mathrm{g}$ PNP $g^{-1} d w$ soil $h^{-1}$, DHA by Casida et al. [25] and expressed as $\mu \mathrm{g}$ TPF $g^{-1} d w$ soil $h^{-1}$ whereas GSA was determined by Eivazi and Tabatabai [26] method and expressed as $\mu \mathrm{g}$ PNG $g^{-1} d w$ soil $h^{-1}$.

\subsection{Statistical Analysis}

All statistical analysis like ANOVA, Kruskal-Wallis $\mathrm{H}$ test, paired sampled $t$-test, principal component analysis (PCA) were performed in software package IBM SPSS Statistics 20.0 for Windows. Paired sample $t$-test was performed to test the significant differences in soil variables between RS and BS. The three fallow phases were compared in terms of every parameter analyzed by the non-parametric Kruskal-Wallis $\mathrm{H}$ test, incorporating 1000 randomizations at a Monte-Carlo test of significance with a $99 \%$ confidence limit. One-way analysis of variance (Tukey's HSD) was performed to test the rhizosphere effects on soil microbial properties of different fallow phase. The magnitude of the rhizosphere effect was calculated as the percentage difference between paired RS and BS samples for each soil variable.

\section{RESULTS}

\subsection{Soil Physico-chemical and Microbial Properties between Rhizosphere and Bulk Soil}

The SMC in RS was significantly higher $(p<0.05)$ than BS and the SMC in RS and BS ranged from $23.6 \%-27.2 \%$ and $20.7 \%-22.8 \%$ respectively. 
Soil $\mathrm{pH}$ showed significant difference between RS and BS in FP-2 and FP-5 (Table 1). Similarly, amount of SOC and TN in RS was significantly higher $(p<0.05)$ compared to BS for all the sites except in FP-2, where no significant difference in TN between RS and BS (Table 1). The SOC and $\mathrm{TN}$ in $\mathrm{RS}$ range from $2.8 \%-3.1 \%$ and $0.27 \%-$ $0.30 \%$ respectively whereas in BS, the SOC and TN range from $2.1 \%-2.6 \%$ and $0.26 \%-0.27 \%$ respectively (Table 1). The MBC and MBN values were significantly higher $(p<0.05)$ in $R S$ compared to BS far all the sites. The highest amount of MBC in was recorded in RS of FP-10 $\left(551 \mu \mathrm{g} \mathrm{g}^{-1}\right)$ and lowest in BS of FP-2 $(349 \mu \mathrm{g} \mathrm{g}$ $\left.{ }^{1}\right)$. The amount of MBN in RS range from $36 \mu \mathrm{g}$ $\mathrm{g}^{-1}-46 \mu \mathrm{g} \mathrm{g}^{-1}$ whereas it ranges from $17 \mu \mathrm{g} \mathrm{g}^{-1}-$ $34 \mathrm{\mu g} \mathrm{g}^{-1}$ (Table 2). Correspondingly, the value of APA showed significant variation between RS and BS, however, no significant changed between RS and BS in DHA for all the sites (Table 2). The value of GSA marked significant variation between RS and BS in FP-2 and FP-10 but no significant variation in FP-5 (Table 2). The highest value of APA was recorded in RS of FP$10\left(1462 \mu \mathrm{g}\right.$ PNP g ${ }^{-1}$ soil $\left.^{-1}\right)$ and lowest in BS of

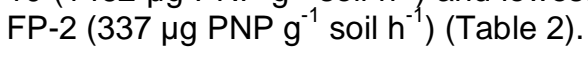

\subsection{Variability in Soil Variables as Influenced by Fallow Phase}

The three fallow phases (FP-2, FP-5 and FP-10 years) showed significant variation in terms of SMC, pH, SOC, MBC, APA and GSA for RS but no significant variation in TN, MBN and DHA, on the other hand, significant variation was marked in soil $\mathrm{pH}, \mathrm{MBC}, \mathrm{MBN}$ and APA whereas no significant changed in SMC, SOC, TN, GSA and DHA for BS ( $P>0.05$; Kruskal-Wallis $H$ test

Table 1. Soil moisture content (SMC), soil pH, soil organic carbon (SOC) and total nitrogen (TN) in rhizosphere soil (RS) and bulk soil (BS) of different fallow phases, Mizoram

\begin{tabular}{llllll}
\hline Soil & Fallow phase & $\begin{array}{l}\text { MC } \\
(\%)\end{array}$ & pH & $\begin{array}{l}\text { SOC } \\
(\%)\end{array}$ & $\begin{array}{l}\text { TN } \\
(\%)\end{array}$ \\
\hline Rhizosphere soil & 2 years & $23.6(4.8)^{\mathrm{a}}$ & $4.23(0.3)^{\mathrm{a}}$ & $2.8(0.1)^{\mathrm{a}}$ & $0.27(0.01)^{\mathrm{a}}$ \\
& 5 years & $25.1(5.7)^{\mathrm{a}}$ & $4.56(0.2)^{\mathrm{a}}$ & $2.9(0.1)^{\mathrm{a}}$ & $0.29(0.02)^{\mathrm{a}}$ \\
& 10 years & $27.2(5.3)^{\mathrm{a}}$ & $4.96(0.3)^{\mathrm{a}}$ & $3.1(0.1)^{\mathrm{a}}$ & $0.30(0.02)^{\mathrm{a}}$ \\
Bulk soil & Monte Carlo Sig. & 0.044 & 0.037 & 0.042 & 0.200 \\
& 2 years & $20.7(4.3)^{\mathrm{b}}$ & $4.46(0.2)^{\mathrm{b}}$ & $2.1(0.1)^{\mathrm{b}}$ & $0.26(0.01)^{\mathrm{a}}$ \\
& 5 years & $21.9(4.9)^{\mathrm{b}}$ & $4.71(0.4)^{\mathrm{b}}$ & $2.3(0.2)^{\mathrm{b}}$ & $0.26(0.05)^{\mathrm{b}}$ \\
& 10 years & $22.8(5.7)^{\mathrm{b}}$ & $4.98(0.4)^{\mathrm{a}}$ & $2.6(0.2)^{\mathrm{b}}$ & $0.27(0.05)^{\mathrm{b}}$ \\
& Monte Carlo Sig. & 0.314 & 0.037 & 0.124 & 0.229 \\
\hline
\end{tabular}

Values are means of 4 replicates \pm standard deviation. From each fallow phase, differences in soil variable between $R S$ and BS were determined by paired sample t-test. Same letters indicate non-significant difference between RS and BS. Variation in soil parameters in different fallow phase were determined by non-parametric Kruskal-Wallis H test (1000 randomization) incorporating Monte Carlo significance at 99\% confidence limits

Table 2. Microbial biomass carbon (MBC), microbial biomass nitrogen (MBN), acid phosphatase activity (APA), $\beta$-glucosidase activity (GSA) and dehydrogenase activity (DHA) in rhizosphere soil (RS) and bulk soil (BS) of different fallow phases, Mizoram

\begin{tabular}{|c|c|c|c|c|c|c|}
\hline Soil & Fallow phase & $\begin{array}{l}\text { MBC } \\
\left(\mu \mathrm{g} \mathrm{g}^{-1}\right)\end{array}$ & $\begin{array}{l}\text { MBN } \\
\left(\mu g^{-1}\right)\end{array}$ & $\begin{array}{l}\text { APA } \\
\left(\mu \mathrm{g} \mathrm{PNP}^{-1}\right. \\
\left.\text { soil }^{-1}\right)\end{array}$ & $\begin{array}{l}\text { GSA } \\
\left(\mu \mathrm{PNG} \mathrm{g}^{-1}\right. \\
\left.\text { soil }^{-1}\right)\end{array}$ & 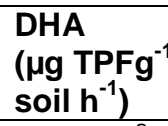 \\
\hline \multirow[t]{4}{*}{ Rhizosphere soil } & 2 years & $469(69)^{a}$ & $36(7)^{a}$ & $425(55)^{\mathrm{a}}$ & $29.5(1.1)^{\mathrm{a}}$ & $5.4(1.7)^{\mathrm{a}}$ \\
\hline & & $503(74)^{a}$ & $39(9)^{a}$ & $628(68)^{a}$ & $29.6(0.5)^{\mathrm{a}}$ & $6.7(2.0)^{a}$ \\
\hline & 10 years & $551(69)^{a}$ & $46(12)^{a}$ & $1462(85)^{\mathrm{a}}$ & $39.9(1.1)^{\mathrm{a}}$ & $6.8(2.7)^{\mathrm{a}}$ \\
\hline & Monte Carlo Sig. & 0.001 & 0.438 & 0.014 & 0.015 & 0.668 \\
\hline \multirow[t]{4}{*}{ Bulk soil } & 2 years & $349(46)^{b}$ & $17(5)^{\mathrm{b}}$ & $337(20)^{\mathrm{b}}$ & $25.2(0.3)^{\mathrm{b}}$ & $4.6(0.1)^{\mathrm{a}}$ \\
\hline & 5 years & $401(63)^{b}$ & $26(8)^{b}$ & $347(70)^{b}$ & $26.9(2.4)^{\mathrm{a}}$ & $5.5(0.7)^{\mathrm{a}}$ \\
\hline & 10 years & $443(54)^{b}$ & $34(9)^{b}$ & $648(18)^{b}$ & $27.2(2.4)^{b}$ & $5.9(1.5)^{\mathrm{a}}$ \\
\hline & Monte Carlo Sig. & 0.001 & 0.017 & 0.006 & 0.749 & 0.265 \\
\hline
\end{tabular}

Values are means of 4 replicates \pm standard deviation. From same fallow phase, differences in soil variable between RS and BS were determined by paired sample t-test. Same letters indicate non-significant difference between RS and BS. Variation in soil parameters in different fallow phase were determined by non-parametric Kruskal-Wallis H test (1000 randomization) incorporating Monte Carlo significance at 99\% confidence limits 
incorporating Monte-Carlo significance at 99\% confidence limit; Tables 1 and 2). The overall variability of different fallow phase in RS and BS were presented in Fig. $1 \mathrm{a}$ and $\mathrm{b}$ respectively. PCA generated two distinct clusters with FP-2 and FP-5 separated from FP-10 in RS with PC1 $(50.41 \%)$ and PC2 $(21.87 \%)$ and BS with PC1 (65.36\%) and PC2 (17.37\%) (Fig.1 a and b). The magnitude of rhizosphere effect of $M$. baccifera in different fallow period was listed in Table 3. The results showed that rhizosphere effect was greater in 2 years fallow for different soil variables except in APA and GSA. The rhizosphere effect in SOC ranged from $40-89 \%$, TN (5-12\%), MBC (24-34\%), MBN (34-111\%), APA (56-126\%), GSA (17-48) whereas no significant rhizosphere effect was marked in DHA. Correlation analyses (data not given) showed that SOC positively significantly correlated with MBC $\left(r^{2}=0.447, P<0.009\right)$, MBN $\left(r^{2}=0.392, P<0.032\right)$, APA $\left(r^{2}=402, P<0.002\right)$ but negatively correlated with soil $\mathrm{pH}\left(r^{2}=-0.419\right.$, $P<0.05)$ whereas $\mathrm{TN}$ positively significantly correlated with MBC $\left(r^{2}=0.730, P<0.001\right), M B N$ $\left(r^{2}=0.590, P<0.001\right)$, APA $\left(r^{2}=0.741, P<0.001\right)$, GSA $\quad\left(r^{2}=0.699, \quad P<0.002\right) \quad$ but negatively correlated with soil $\mathrm{pH}\left(\mathrm{r}^{2}=-0.527, P<0.527\right)$ and SMC $\left(r^{2}=-0.149, P<0.075\right)$.

\section{DISCUSSION}

\subsection{SOC, TN and pH in Rhizosphere and Bulk Soil}

The rhizosphere is a narrow zone with high microbial activity and turnover rates driven by plant root exudates, making its chemical and microbial properties usually distinct from those of BS [9]. Root exudates affect nutrient cycling by stimulating rhizosphere microbial growth and altering their community structure [27]. In the current study, the RS of $M$. baccifera showed higher SOC and TN than BS. The result of increase SOC and TN in RS may be due to rhizodeposition, which may account for as much as $25 \%$ of the $\mathrm{C}$ allocated belowground (or $10 \%$ of the net fixed $\mathrm{C}$ and $\mathrm{N}$ ) $[28,29]$. The change in rhizosphere $\mathrm{pH}$ has been demonstrated by several researchers $[2,30,31]$. The changes in soil $\mathrm{pH}$ in the present study were similar to that in rhizosphere of silver birch by Rosenvald et al. [32] and Zhang et al. [30]. Root exudation of organic anions as well as respiration in alkaline soils, cation-anion exchange balance by roots, and redox-coupled processes may be responsible for decrease soil $\mathrm{pH}$ in $\mathrm{RS}$.

\subsection{Microbial Properties in Rhizosphere and Bulk Soil}

The current study shows that RS of $M$. baccifera have higher MBC and MBN contents compared to BS. A similar trend was marked in enzyme activities like APA and GSA except in DHA. The results in present studies are in consistent with those of earlier studies $[7,33,34]$. These results suggest that the rhizosphere microbes are more dynamic and active than those in the BS. Enhanced microbial properties in RS may be due to root exudation such as sugars, acids, hormones, sloughed root cells and C allocated to root-associated symbionts. These substrates provide favorable resources for the microbial population. By contrast, there is no significant variation in DHA between RS and BS. This finding is in contrast to the results reported by Nosalewicz and Nosalewicz [35]. The nonsignificant variation in DHA between RS and BS may be related to the compositions of microbial communities in rhizosphere. Buee et al. [36] and Koranda et al. [9] described that soil enzyme activities are formed by some specialized groups of microorganisms through an $r$ or $\mathrm{K}$ strategy, e.g. phosphatase produced by mycorrhizal fungi. These microorganisms have different capacities to assimilate plant derived $\mathrm{C}$ sources.

Table 3. Magnitudes of rhizosphere effects (\%) of bamboo ( $M$. baccifera) on soil in different fallow land $(n=4)$ following shifting cultivation in Mizoram

\begin{tabular}{|c|c|c|c|c|c|c|c|}
\hline Fallow & SOC & TN & MBC & MBN & APA & GSA & DHA \\
\hline 2 years & $82^{\mathrm{a}}$ & $5^{b}$ & $34^{\mathrm{a}}$ & $111^{\mathrm{a}}$ & $56^{\mathrm{C}}$ & $17^{\mathrm{b}}$ & NS \\
\hline 5 years & $59^{b}$ & $11^{\mathrm{a}}$ & $25^{b}$ & $45^{\mathrm{b}}$ & $81^{b}$ & $\mathrm{NS}^{\mathrm{c}}$ & NS \\
\hline 10 years & $40^{c}$ & $12^{\mathrm{a}}$ & $24^{\mathrm{b}}$ & $34^{\mathrm{b}}$ & $126^{\mathrm{a}}$ & $48^{\mathrm{a}}$ & NS \\
\hline
\end{tabular}

(DHA), $\beta$-glucosidase activity (GSA) 

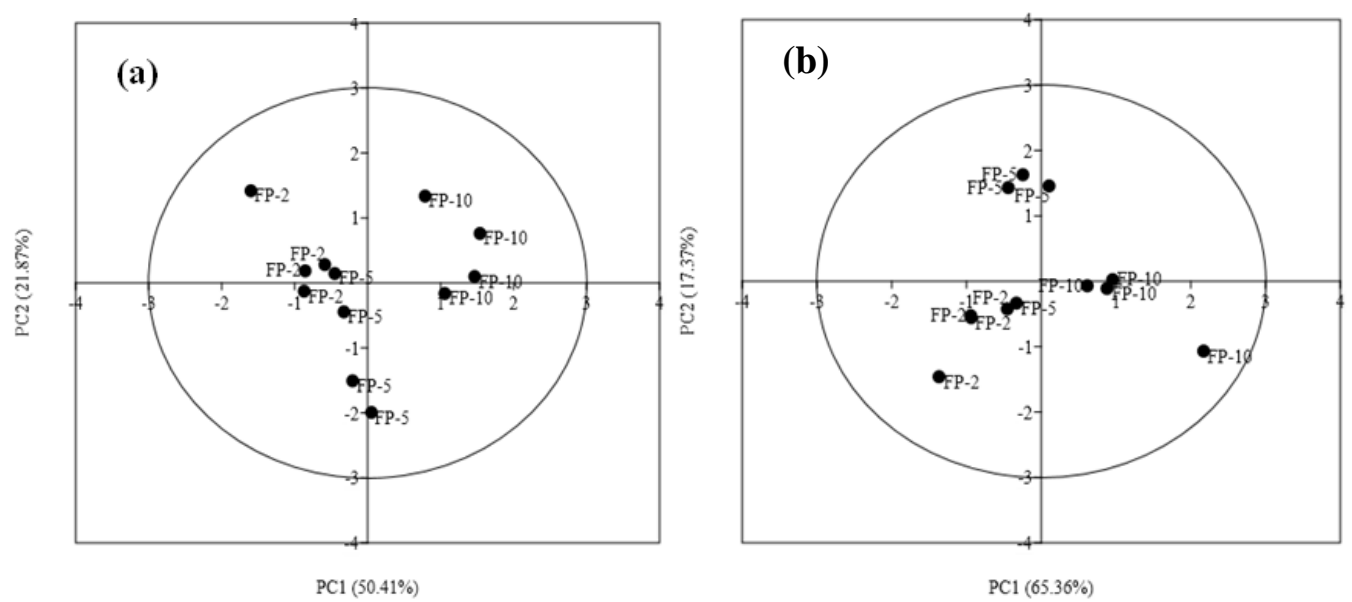

Fig. 1. Scores of the first two principal components of microbial properties in (a) rhizosphere soil (b) bulk soil of different fallow phase e.g. 2 years fallow phase (FP-2), 5 years fallow phase (FP-5) and 10 years fallow phase (FP-10) in Mizoram

\subsection{Rhizosphere Effects of $M$. baccifera in Different Fallow Phase}

The amount of organic matter buildup during the course of succession in moist tropical forest of Mizoram is originally influenced by the length of fallow phase and thus the stands with higher abandoned age supports greater crop productivity [13]. $M$. bacciferra is a secondary successional species that recover quickly during the course of succession and often regenerate through rhizome during the cropping phase and interact with crops. The fallow phase can significantly influence the microbial properties in the plant rhizosphere. In the current investigation, the amount of $\mathrm{SOC}$ and $\mathrm{TN}$ in rhizosphere was significantly increased in longer fallow phase. These results indicate that the RS of $M$. baccifera in long fallow phase has greater potential to enhance SOC and TN compared to short fallow phase. Similarly, the amount of MBC and MBN significantly enhance with increase fallow phase demonstrating increased microbial activities on nutrient substrates. A similar result was observed by Rosenvald et al. [32] in their investigation of the rhizosphere soil microbial properties in a chronosequence of silver birch stands on reclaimed post-mining areas. Similarly, the amount of APA and GSA increased considerably from shorter fallow to longer fallow phase. A possible reason for decline in enzyme activities in short fallow phase may be the result of nutrient limitations whereas in longer fallow phase, adequate supply of nutrient substrate through organic matter decomposition may enhance the rate of microbial activity. The findings in current investigation is consistent with the result reported in rhizosphere microbial properties of successional annual plants (Artemisia capillaries and $A$. sacrorum) in semiarid region of Loess plateau, China [30]. Tarafdar and Jungk [37] carried out a very interesting study on the relationship between soil enzyme activity and nutrient cycling in the rhizosphere and their result demonstrated that enzyme activities increased with plant age, probably due to increase in microbial biomass and/or the increase in total root surface area. Furthermore, the low nutrient availability in the short fallow phase possibly inhibits the microbial utilization of $\mathrm{C}$ released by the roots. However, in the longer fallow phase, increased soil nutrients fueled microbial growth and activity $[38,39]$.

The result in present finding indicates increase microbial properties with fallow phase. On contrary to this result, the magnitude of rhizosphere effect of $M$. baccifera is greater in shorter fallow phase than longer fallow phase which is in conformity with our hypothesis. The greater rhizosphere effect in short fallow phase may be due to increase root exudation of $M$. baccifera as well as microbial activity in the rhizosphere that tends to build up and sustain nutrient level mainly in low nutrient availability. The improvement of nutrient substrate in BS may also be responsible for reducing the rhizosphere effect in longer fallow phase. Earlier studies reported that the magnitude of rhizosphere effect of Sugar maple and Red oak on biochemical properties were affected by fertilization and their results indicated that rhizosphere effect was 
greater in control plot (without fertilization) compared with fertilized plots [1]. This result shows that the magnitude of rhizosphere effect of plants is largely affected by the soil condition relatively than the host plant. Singh et al. [40] reported that the major factor causing changes in microbial composition in rhizospheres is soil, rather than plants.

\section{CONCLUSION}

The present study shows that the bamboo rhizosphere has significant changes in soil microbial properties in different fallows with greater effect in short fallow phase. It appears that rhizosphere effect of bamboo in young fallow is driven by microbes growing under $\mathrm{C}$ and nutrient limited conditions and the same in older fallows are regulated by the opportunistic soil microbes by exploiting the organic matter and the nutrients accumulated there. Further studies are needed to assess the changes in rhizosphere microbes in different fallow phases.

\section{ACKNOWLEDGEMENTS}

We thank Dr. N.C. Talukdar, Director, IASST for comments and suggestions from time to time. Authors are thankful to Dr. Diwpendra Thakuria, Central Agriculture University, Umiam, Meghalaya for providing laboratory facility and assist in analysis of soil enzyme activity. Authors are also thankful to the Department of Biotechnology (DBT) for financial support in the form of a research project. First author is also thankful to University Grants Commission, New Delhi for financial support in the form of a Rajiv Gandhi National Fellowship.

\section{COMPETING INTERESTS}

Authors have declared that no competing interests exist.

\section{REFERENCES}

1. Phillips RP, Fahey TJ. Tree species and mycorrhizal associations influence the magnitude of rhizosphere effects. Ecology. 2006;87:1302-1313.

2. Zhao Q, Zeng DH, Fan ZP. Nitrogen and phosphorus transformations in the rhizospheres of three tree species in a nutrient poor sandy soil. Applied Soil Ecology. 2010;46:341-346.

3. Phillips RP, Meier IC, Bernhardt ES, Grandy AS, Wickings K, Finzi AC. Roots and fungi accelerate carbon and nitrogen cycling in forests exposed to elevated $\mathrm{CO}_{2}$. Ecology Letters. 2012;15:1042-1049.

4. Chanway CP. Plant growth promotion by Bacillus and relatives. In Berkeley $R$, Heyndrickx M, Logan N, De Vos P. (Eds). Applications and systematics of Bacillus and relatives. Blackwell, Oxford, UK. 2002; 219-235.

5. Marschner $\mathrm{H}$. Mineral nutrition of higher plants, $2^{\text {nd }}$ edition. Academic Press, San Diego. 1995;889.

6. Steer J, Harris JA. Shifts in the microbial community in rhizosphere and nonrhizosphere soils during the growth of Agrostis stolonifera. Soil Biology \& Biochemistry. 2000;32:869-878.

7. Tscherko D, Ute H, Marie-Claude M, Ellen K. Shifts in rhizosphere microbial communities and enzyme activity of Poa alpina across an alpine chronosequence. Soil Biology \& Biochemistry. 2004;36:1685 -1698 .

8. Esperschütz J, Buegger $\mathrm{F}$, Winkler JB, Munch JC, Schloter M, Gattinger A. Microbial response to exudates in the rhizosphere of young beech trees (Fagus sylvatica L.) after dormancy. Soil Biology \& Biochemistry. 2009;41:1976-1985.

9. Koranda M, Schnecker J, Kaiser C, Fuchslueger L, Kitzler B, Stange CF, Sessitsch A, Sophie ZB, Richter A. Microbial processes and community composition in the rhizosphere of European beech the in $f$ puence of plant $C$ exudates. Soil Biology \& Biochemistry. 2011;43:551-558.

10. Martínez-Iñigo MJ, Pérez-Sanz A, Ortiz I, Alonso J, Alarcón R, Garcia P, Lobo MC. Bulk soil and rhizosphere bacterial community PCR-DGGE profiles and $\beta$ galactosidase activity as indicators of biological quality in soils contaminated by heavy metals and cultivated with Silene vulgaris (Moench) Garcke. Chemosphere. 2009;75:1376-1381.

11. Sinha S, Masto RE, Ram LC, Selvi VA, Srivastava NK, Tripathi RC, Goerge J. Rhizosphere soil microbial index of tree species in a coal mining ecosystem. Soil Biology \& Biochemistry. 2009;41:18241832.

12. Tripathi SK, Vanlalfakawma DC, Lalnunmawia F. Shifting cultivation on steep slopes of Mizoram, India: Impact of policy reforms. In: Cairns M. (ed.), shifting cultivation policy in the Asia-Pacific region: 
Trying to get it right: Routledge, London. (In press); 2015.

13. Grogan P, Lalnunmawia F, Tripathi SK. Shifting cultivation in steeply sloped regions: A review of management options and research priorities for Mizoram state, Northeast India. Agroforestry Systems. 2012;84:163-177.

14. Singh J, Bora IP, Baruah A, Hussain M. Effect of shifting cultivation on nutrient status of soil in Silonijan (Karbi Anglong) Assam. Indian Forestry. 2003;129(11): 1329-1338.

15. Watanabe M. A proposal on the life form of bamboos and ecological bamboo forests, in: Bamboo production and utilization, proceedings of the project group p 5.04, $18^{\text {th }}$ IUFRO World Congress, Higuchi, T, (Ed.). Japan Society of Bamboo Development and Protection; 1986.

16. Banik RL. Annual growth periodicity of culm and rhizome in adult clumps of Melocanna baccifera (Roxb.) Kurz. Bangladesh Journal of Forest Science.1999;28(1):7-12.

17. Arunachalam A, Arunachalam K. Evaluation of bamboos in eco-restoration of 'jhum' fallows in Arunachal Pradesh: Ground vegetation, soil and microbial biomass. Forest Ecology Management. 2002;159:231-239.

18. Rao KS, Ramakrishnan PS. Role of bamboos in nutrient conservation during secondary succession following slash and burn agriculture (jhum) in North-east India. Journal of Applied Ecology.1989;26:625633.

19. Saplalrinliana H. Plant litter-soil interactions and biochemical index of soil fertility in jhum agro ecosystem. Thesis submitted in college of post-graduate studies (Central Agriculture University, Imphal), Umiam, Meghalaya. 2016;73.

20. Walkley A. Critical examination of rapid method for determining organic carbon in soils: Effect of variation in digestion conditions and of inorganic soil constituents. Soil Science. 1947;63:251257.

21. Brookes PC, Joergensen RG. Microbial biomass measurements by fumigationextraction. In: Bloem J, Hopkins DW, Benedetti A, (Eds.). Microbiological Methods for Assessing Soil Quality. CABI Publishing, Oxfordshire, UK. 2006;77-83.
22. Vance ED, Brookes PC, Jenkinson DS. An extraction method for measuring soil microbial biomass. C. Soil Biology \& Biochemistry. 1987;19:703-707.

23. Jenkinson DS. Determination of microbial biomass carbon and nitrogen in soil. In: Wilson JR. (Ed.). Advances in nitrogen cycling in agricultural systems. $\mathrm{CAB}$ International, Wallingford, UK.1988;368386.

24. Tabatabai MA. Soil enzymes. In methods of soil analysis. Part 2: Microbial and microbial properties, Weaver RW, Angel JS, Bottomley PS, (Eds.). Soil Science Society America, Madison, WI, USA. 1994; 775-833.

25. Casida Jr LE, Klein DA, Santoro T. Soil dehydrogenase activity. Soil Science.1964; 98:371-376.

26. Eivazi F, Tabatabai MA. Glucosidases and galactosidases in soils. Soil Biology \& Biochemistry. 1988;20:601-606.

27. Hernesmaa A, Björklöf K, Kiikkilä O, Fritze $\mathrm{H}$, Haahtela K, Romantschuk M. Structure and function of microbial communities in the rhizosphere of Scots pine after treefelling. Soil Biology \& Biochemistry. 2005; 37:777-785.

28. Uren NC. In: Pinton R, Varanini Z, Nannipieri $P$ (Eds.). Types, amounts and possible functions of compounds released into the rhizosphere by soil grown plants. The Rhizosphere. 2007;1-21. Boca Raton.

29. Jones DL, Nguyen C, Finlay RD. Carbon flow in the rhizosphere: Carbon trading at the soil root interface. Plant Soil. 2009; 321:5-33.

30. Zhang C, Liu G, Xue S, Zhang C. Rhizosphere soil microbial properties on abandoned croplands in the Loess Plateau, China during vegetation succession. European Journal of Soil Biology. 2012;50:127-136.

31. Calvaruso C, Collignon C, Kies A, Turpault MP. Seasonal evolution of the rhizosphere effect on major and trace elements of soil solutions of Norway spruce (Picea abies Karst) and Beech (Facus sylvatica) in an acidic forest soils. Soil Science. 2014;4: 323-336.

32. Rosenvald K, Kuznetsova T, Ostonen I, Truu M, Truu J, Uri V, Lõhmus K. Rhizosphere effect and fine-root morphological adaptations in a chrono sequence of silver birch stands on 
reclaimed oil shale post-mining areas. Ecological Engineering. 2011;37:10271034.

33. Martínez-Alcalá I, Walker DJ, Bernal MP. Chemical and biological properties in the rhizosphere of Lupinus albus alter soil heavy metal fractionation. Ecotoxicology and Environmental Safety. 2010;73:595602.

34. Tu Z, Chen L, Yu X, Zheng Y. Rhizosphere soil enzymatic and microbial activities in bamboo forests in southeastern China. Soil Science and Plant Nutrition. 2014;60:134-144.

35. Nosalewicz A, Nosalewicz M. Effect of soil compaction on dehydrogenase activity in bulk soil and rhizosphere. International Agrophysics. 2011;25:47-51.

36. Buee M, De Boer W, Martin F, Van overbeek L, Jurkevitch $\mathrm{E}$. The rhizosphere zoo: An overview of plant-associated communities of microorganisms, including phages, bacteria, archaea, and fungi, and of some of their structuring factors. Plant Soil. 2009;321:189-212.
37. Tarafder JC, Jungk A. Phosphatase activity in the rhizosphere and its relation to the depletion of soil organic phosphorus. Biology and Fertility of Soils. 1987;3:199204.

38. Liljeroth E, VanVeen JA, Miller HJ. Assimilate translocation to the rhizosphere of two wheat lines and subsequent utilization by rhizosphere microorganisms at two soil nitrogen concentrations. Soil Biology \& Biochemistry. 1990;22:10151021.

39. Grayston SJ, Vaughan D, Jones D. Rhizosphere carbon flow in trees, in comparison with annual plants: The importance of root exudation and its impact on microbial activity and nutrient availability. Applied Soil Ecology. 1996;5: 29-56.

40. Singh BK, Munro S, Potts JM, Millard P. Influence of grass species and soil type on rhizosphere microbial community structure in grassland soils. Applied Soil Ecology. 2007;36:147-155.

(c) 2017 Hauchhum and Tripathi; This is an Open Access article distributed under the terms of the Creative Commons Attribution License (http://creativecommons.org/licenses/by/4.0), which permits unrestricted use, distribution, and reproduction in any medium, provided the original work is properly cited.

Peer-review history:

The peer review history for this paper can be accessed here: http://sciencedomain.org/review-history/19756 